\title{
Mineral deposition at dental adhesive resin containing niobium pentoxide
}

\author{
Fabrício Mezzomo Collares ${ }^{1 *}$, Fernando Freitas Portella ${ }^{1}$, Guilherme Casara da Silva Fraga², \\ Samantha Mendes Semeunka², Lucas de Castro Bartelega Almeida², Emerson da Rosa Santos², \\ Vicente Castelo Branco Leitune ${ }^{1}$ and Susana Maria Werner Samuel ${ }^{1,2}$
}

\author{
* Correspondence: \\ fabricio.collares@ufrgs.br \\ ${ }^{1}$ Dental Materials Laboratory, School \\ of Dentistry, Federal University of \\ Rio Grande do Sul, Rua Ramiro \\ Barcelos 2492, Porto Alegre, RS \\ 90035-003, Brazil \\ Full list of author information is \\ available at the end of the article
}

\begin{abstract}
The aim of this study was to asses in vitro the potential of methacrylate-based adhesive resins containing niobium pentoxide $\left(\mathrm{Nb}_{2} \mathrm{O}_{5}\right)$ for stimulating phosphate deposition. Adhesive resins were obtained by mixing $50 \mathrm{wt} \%$ BisGMA, $25 \mathrm{wt} \%$ TEGDMA and $25 \mathrm{wt} \% \mathrm{HEMA}$, and $\mathrm{Nb}_{2} \mathrm{O}_{5}$ was added on 2.5 or $5 \mathrm{wt} \%$ to the resin. Discs $6.5 \mathrm{~mm}$ in diameter and $1.5 \mathrm{~mm}$ in height of the resin without $\mathrm{Nb}_{2} \mathrm{O}_{5}$ and of the resins presenting the oxide were obtained by inserting the resin into a silicon matrix, followed by photo activation. Discs were immersed in simulated body fluid at $36^{\circ} \mathrm{C}$ for 1,7 and 28 days, and then their surfaces were examined by Raman spectroscopy. Changes of intensity of the $962 \mathrm{~cm}^{-1}$ peak, related to phosphate bond, over the samples' surfaces were used to assess the potential of adhesive resins to stimulate phosphate deposition. Experimental groups containing 2.5 and $5 \mathrm{wt} \%$ niobium pentoxide presented a phosphate-rich layer deposition over their surfaces after 7 and 28 days of SBF immersion, and this deposition increased over time. Incorporation of 2.5 or $5 \mathrm{wt} \%$ niobium pentoxide provides the potential to promote phosphate deposition on methacrylate-based adhesive resins.
\end{abstract}

Keywords: Adhesive systems; Bioactive; Calcium phosphates; Niobium pentoxide; Raman

\section{Springer}

\section{Background}

Advances in enamel and dentin bonding enable the predictability of direct restorative treatments [1]. A reliable dentin bond was achieved by the establishment of a hybrid layer, which is defined as a layer composed of collagen fibrillar matrix surrounded by a polymer formed from monomers previously diffused into the collagen matrix [2]. Discrepancies in etching depth and monomer diffusion depth could generate a region of denuded collagen at the bottom of the hybrid layer [2]. Besides, the presence of residual solvent and fluid movement of dentinal tubules into the co-monomer mixtures of adhesives jeopardize the water replacement by resins into the collagen matrix, leading to an incomplete monomer infiltration [3]. With dentin demineralization by acid-etching, matrix metalloproteinases (MMPs) are activated $[2,4]$, which in association with the susceptibility to hydrolytic degradation of polymers [5], primarily on non-

(c) 2014 Collares et al; licensee Springer. This is an Open Access article distributed under the terms of the Creative Commons Attribution License (http://creativecommons.org/licenses/by/4.0), which permits unrestricted use, distribution, and reproduction in any medium, provided the original work is properly credited. 
infiltrated collagen regions at the bottom of the hybrid layer [4], could contribute to the degradation of the bonding interface [6].

In order to surpass this problem, one option would be to develop an adhesive system that would induce the release of ions with the goal of filling this exposed collagen fiber region with mineral formation [7-11]. Niobium pentoxide $\left(\mathrm{Nb}_{2} \mathrm{O}_{5}\right)$ has shown mineralization induction through mineral deposition in previous studies [12-14], demonstrating promising proprieties. $\mathrm{Nb}_{2} \mathrm{O}_{5}$ was also evaluated as a filler for adhesive resins and methacrylate-based endodontic cements and enhances the Knoop microhardness and radiopacity of these materials $[15,16]$. Besides, $\mathrm{Nb}_{2} \mathrm{O}_{5}$ presents the ability to diffuse into the hybrid layer when inserted into an adhesive resin applied following the etching and primer application in a 3-step etch-and-rinse adhesive system [16]. Therefore, the purpose of this study was to asses in vitro the potential of stimulating phosphate deposition of methacrylate-based adhesive resins containing niobium pentoxide.

\section{Methods}

\section{Formulation of experimental adhesives}

Adhesive resins were obtained by mixing $50 \mathrm{wt} \%$ BisGMA, $25 \mathrm{wt} \%$ TEGDMA and 25 wt\% HEMA (provided by Esstech Inc, Essington, PA, USA). Camphoroquinone (Sigma Aldrich, USA) and ethyl 4-dimethylaminobenzoate (Sigma Aldrich, USA) were added at $1 \mathrm{~mol} \%$ to the mixture to achieve a photo-activated blend. Niobium pentoxide $\left(\mathrm{Nb}_{2} \mathrm{O}_{5}\right.$, Companhia Brasileira de Metalurgia e Mineração, Araxá, MG, Brazil) was added at 2.5 and $5 \mathrm{wt} \%$, in relation to the mass of the experimental adhesives, and one adhesive without $\mathrm{Nb}_{2} \mathrm{O}_{5}$ was used as a control. $\mathrm{Nb}_{2} \mathrm{O}_{5}$ was previously silanized using $\gamma$ methacryloxypropyltrimethoxysilane ( $\gamma$-MPTS, Aldrich Chemical Co., Milwaukee, WI, USA) [17]. Reagents were hand mixed and sonicated for $180 \mathrm{~s}$.

\section{Phosphate deposition assay by Raman spectroscopy}

Adhesive resin was inserted into a cylindrical silicon matrix of $6.5 \mathrm{~mm}$ diameter and $1.5 \mathrm{~mm}$ height, covered by a polyester film and photo activated (Radii Cal1200 mW/ $\mathrm{cm}^{2}$, SDI LTD., Bayswater, VIC, Australia) for $20 \mathrm{~s}$ on each side. Three discs were obtained for each experimental adhesive. Discs were immersed in simulated body fluid (SBF) prepared according to Kokubo and Takadama [18] for 1,7 or 28 days at $36^{\circ} \mathrm{C}$. The SBF prepared had the following ion concentration in $\mathrm{mol} / \mathrm{m}^{3}: \mathrm{Na}^{+}(213.0), \mathrm{K}^{+}$ (7.5), $\mathrm{Mg}^{2+}$ (2.3), $\mathrm{Ca}^{2+}$ (3.8), $\mathrm{Cl}^{-}$(221.7), $\mathrm{HCO}^{3-}$ (6.3), $\mathrm{HPO}_{4}^{3-}$ (1.5) and $\mathrm{SO}_{4}^{2-}(0.8)$, and the $\mathrm{pH}$ was adjusted to 7.40. After the storage period, samples were washed with $10 \mathrm{ml}$ of distilled water and dried on desiccators at $36^{\circ} \mathrm{C}$.

Chemical changes on the sample surface were analyzed by Raman spectroscopy (Senterra, Bruker Optics, Ettlingen, Germany). An area of 200x200 $\mu$ m was irradiated three times for $5 \mathrm{~s}$ by a $785-\mathrm{nm}$ laser of $50 \mathrm{~mW}$ on 100 equidistant points. Spectra were obtained at 1800 to $440 \mathrm{~cm}^{-1}$ Raman band. Using spectroscopy software (Opus 7.5, Bruker Optics, Ettlingen, Alemanha), the integral of the $962 \mathrm{~cm}^{-1}$ peak absorbance (symmetric stretching $v_{1}$ mode of phosphate) [19] and of the $1610 \mathrm{~cm}^{-1}$ peak (vibration mode of carbon-to-carbon stretching of the aromatic ring of BisGMA) [20], as indicated in Figure 1, was calculated. Increases in the ratio between the absorbance of the 962 and $1610 \mathrm{~cm}^{-1}$ peaks $\left(A_{962 \mathrm{~cm}}^{-1} / A_{1610 \mathrm{~cm}}^{-1}\right)$ indicate the deposition of calcium phosphates on the samples' surfaces. 


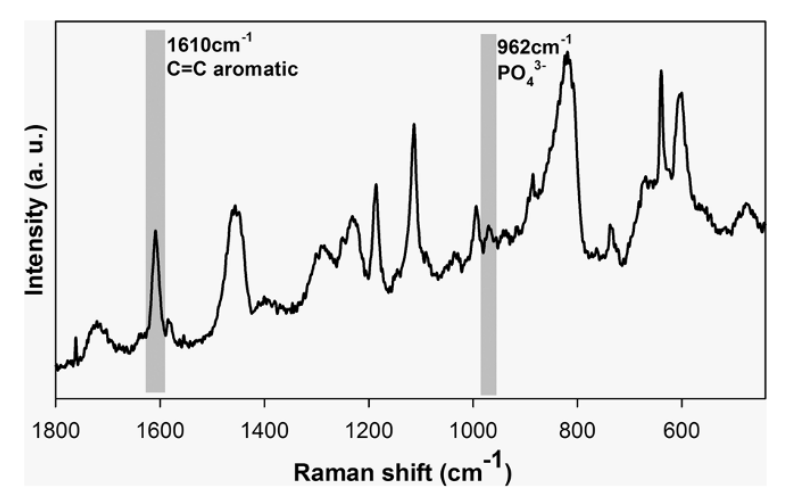

Figure 1 Raman spectrum of adhesive resin containing $5 \%$ of $\mathrm{Nb}_{2} \mathrm{O}_{5}$ after 28 days immersed in SBF. Absorbance bands with 1610 and $962 \mathrm{~cm}^{-1}$ peaks, related to aromatic carbon-to-carbon double bonds and phosphate groups, respectively, were highlighted.

\section{Results and discussion}

Bioactive materials should interact with tissues, evoking positive responses to the host body [21], as this stimulates hard tissue formation. Figure 2 shows phosphate content changes over the sample surface after distinct periods immersed in SBF, assessed by variation in the absorbance of the phosphate Raman peak. Phosphate content increases over time for all groups, being more pronounced in the groups containing 2.5 and $5 \%$ $\mathrm{Nb}_{2} \mathrm{O}_{5}$ than in the control group. Adhesive resins with niobium pentoxide incorporation exhibited phosphate deposition after 7 days of immersion. The presence of niobium pentoxide stimulates the deposition of calcium phosphate from the fluids [12] and allows the material to be bioactive.

Higher content of phosphates $\left(\mathrm{A}_{962 \mathrm{~cm}}^{-1} / \mathrm{A}_{1610 \mathrm{~cm}}^{-1}\right)$ measured at 100 points on each sample after 28 days of SBF immersion reached 0.27 for the control resin, 0.42 for resin with $2.5 \% \mathrm{Nb}_{2} \mathrm{O}_{5}$ and 0.40 for resin with $5 \% \mathrm{Nb}_{2} \mathrm{O}_{5}$. Phosphate deposition on the control resin could be attributed to immersion of a solid sample that could be partially solubilized, evoking $\mathrm{pH}$ changes, altering local supersaturation of SBF and causing spontaneous precipitation of calcium and phosphate ions [22]. Despite this drawback of SBF testing, the adhesive resins containing $\mathrm{Nb}_{2} \mathrm{O}_{5}$ exhibited a more pronounced deposition of phosphates than the control resin. The use of SBF testing to predict bioactivity of biomaterials has been severely questioned [22,23]. It is stated that use of SBF testing leads to false-positive results and cannot reliably mimic physiological conditions [22,23]. A review discussing the in vitro and in vivo bioactivity of calcium silicate cements showed that a material that produced an apatite layer over its surface after interacting with the ions derived from SBF did not exhibit a bone bond when inserted in living tissues [24]. Three different mechanisms of interaction with tissues could contribute to the bioactivity of materials: chemical bonds to host tissues, influence on cellular pathways and stimulus to cell differentiation by topographical features of biomaterial. From these mechanisms, the SBF test simulates only the chemical bond to tissues which could be predicted by their apatite-forming ability on samples surface [25]. Nevertheless, the protocol for in vitro testing of implants using SBF was described 


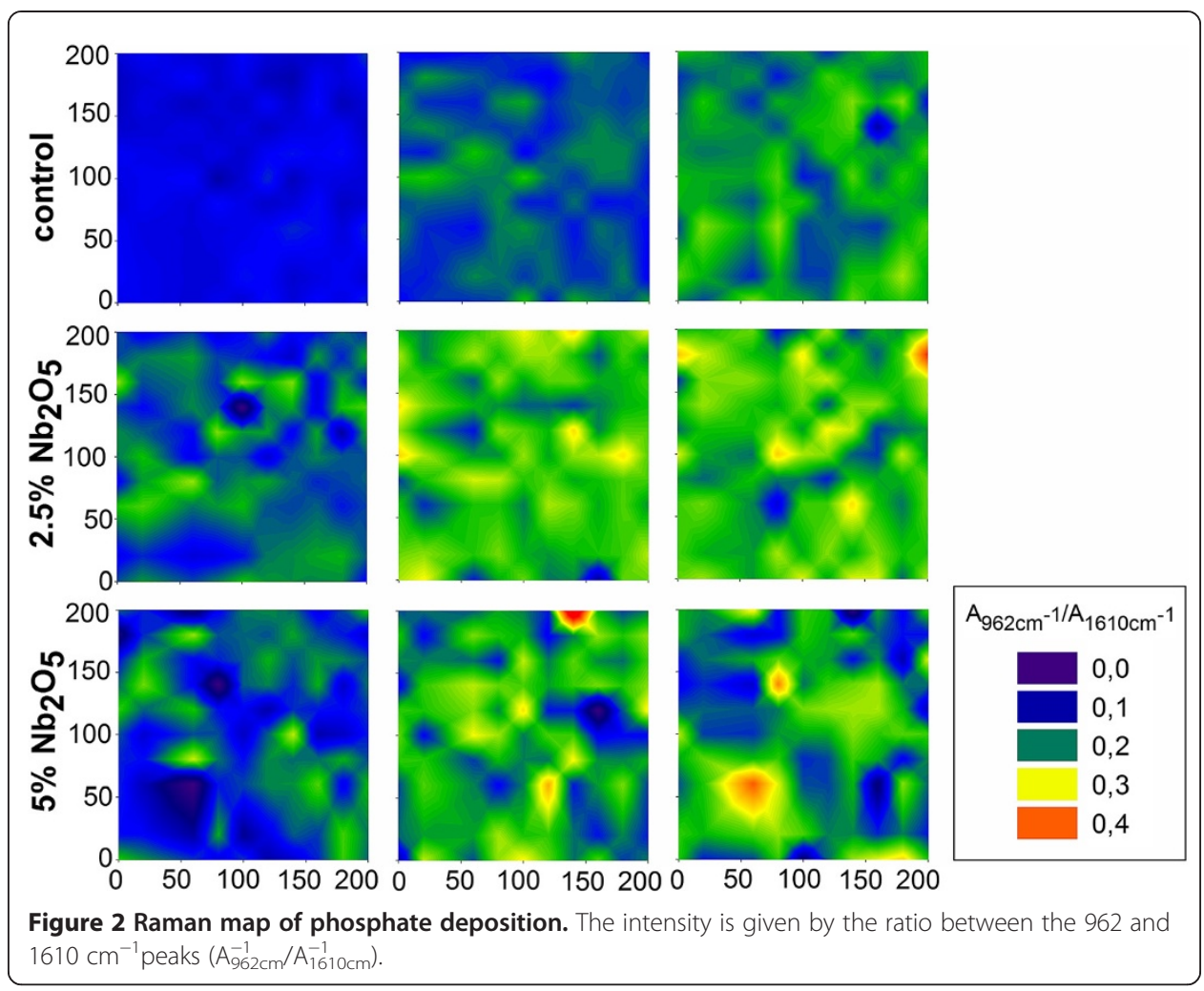

by ISO 23317 [26]. Recently, Zadpoor [25] systematically reviewed the literature, looking for studies that evaluate the bioactivity of two or more biomaterials by SBF immersion and animal models. Of 33 papers included in the analysis, 25 of the results showed that in vitro testing matched the in vivo results. In three the bioactivity was confirmed by in vitro and in vivo tests; however, the materials' bioactivity was not ranked in the same way. In the other five papers, the biomaterials showed no apatite layer in an SBF test but bonded to animals' bone tissue. In this review, no false-positive results were noticed. Thus, the lowcost, rapid speed and ease make the SBF test the method of choice for an initial screening of newly developed materials.

Retention of direct restorative materials currently used is achieved by micromechanical interlocking and/or chemical adhesion [2,27]. Nowadays, the adhesive procedures have a reliable clinical effectiveness [1]. However, some issues remain challenging in achieving a durable bond to tooth structure. During restorative procedures using a separate etching step, a discrepancy between the demineralization depth and monomer penetration could occur [2]. This fact makes the non-monomer-infiltrated collagen at the bottom of the hybrid layer more prone to degradation by proteolytic enzymes, as dentinal matrix metalloproteinases and, consequently, the resin-dentin bonding interface could be compromised [2]. The incorporation of bioactive materials has been proposed, attempting to backfill the denuded collagen to prevent hybrid layer deterioration [8-11]. Calcium silicates and calcium orthophosphates have already been experimentally tested on adhesives aiming at this therapeutic/remineralization effect $[28,29]$. These compounds are highly soluble, and their action is due to an initial solubilization followed by a deposition of minerals [28]. This process does not occur for niobium pentoxide; it is expected that an apatite-like phase directly deposits over its surface 
without an initial dissolution of the mineral due to a $\mathrm{Nb}-\mathrm{OH}$ bond formed on the oxide surface that induces apatite nucleation from SBF ions $[14,30]$. Besides, this does not require the dissolution of filler from the adhesive matrix niobium pentoxide, which enhances the Knoop microhardness and radiopacity of adhesive resins [16]. Thus, we assume that the developed adhesive resins were capable of promoting calciumphosphate deposition on their surfaces and could contribute to the maintenance of hybrid layer integrity.

\section{Conclusion}

Adhesive resins containing 2.5 and 5\% niobium pentoxide stimulated the deposition of a phosphate layer over their surfaces.

\section{Competing interests}

The authors declare that they have no competing interests.

\section{Authors' contributions}

FMC participated in the study design development, manuscript construction and manuscript final review; FFP participated in the study design development, data interpretation and manuscript construction; GCSF participated in the study design development and manuscript construction; SMS, LCBA and ERS participated in laboratory tests; VCBL participated in study design development and manuscript final review; SMWS participated in study design development and manuscript final review. All authors read and approved the final manuscript.

\section{Acknowledgments}

The authors acknowledge financial support from PET-SESU/MEC (Programa de Educação Tutorial, Secretaria de Educação Superior, Ministério da Educação), and FFP gratefully acknowledges scholarship support from CAPES (Coordenação de Aperfeiçoamento de Pessoal de Nível Superior).

\section{Author details}

${ }^{1}$ Dental Materials Laboratory, School of Dentistry, Federal University of Rio Grande do Sul, Rua Ramiro Barcelos 2492, Porto Alegre, RS 90035-003, Brazil. ${ }^{2}$ Tutorial Education Program, School of Dentistry, Federal University of Rio Grande do Sul, Rua Ramiro Barcelos 2492, Porto Alegre, RS 90035-003, Brazil.

Received: 24 October 2014 Accepted: 7 November 2014

Published online: 03 December 2014

\section{References}

1. Peumans M, De Munck J, Mine A, Van Meerbeek B (2014) Clinical effectiveness of contemporary adhesives for the restoration of non-carious cervical lesions. A systematic review. Dent Mater. doi:10.1016/j.dental.2014.07.007

2. Pashley DH, Tay FR, Breschi L, Tjaderhane L, Carvalho RM, Carrilho M, Tezvergil-Mutluay A. (2011) State of the art etch-and-rinse adhesives. Dent Mater 27:1-16

3. Hashimoto M, Tay FR, Svizero NR, de Gee AJ, Feilzer AJ, Sano H. (2006) The effects of common errors on sealing ability of total-etch adhesives. Dent Mater 22:560-568

4. Mazzoni A, Nascimento FD, Carrilho M, Tersariol I, Papa V, Tjaderhane L, Di Lenarda R, Tay FR, Pashley DH, Breschi L. (2012) MMP activity in the hybrid layer detected with in situ zymography. J Dent Res 91:467-472

5. Ferracane $J \mathrm{~L}$ (2006) Hygroscopic and hydrolytic effects in dental polymer networks. Dent Mater 22:211-222

6. Tjaderhane L, Nascimento FD, Breschi L, Mazzoni A, Tersariol IL, Geraldeli S, Tezvergil-Mutluay A, Carrilho MR, Carvalho RM, Tay FR, Pashley DH. (2013) Optimizing dentin bond durability: control of collagen degradation by matrix metalloproteinases and cysteine cathepsins. Dent Mater 29:116-135

7. Reis A, Carrilho M, Breschi L, Loguercio AD (2013) Overview of clinical alternatives to minimize the degradation of the resin-dentin bonds. Oper Dent 38:E1-E25

8. Kim YK, Gu LS, Bryan TE, Kim JR, Chen L, Liu Y, Yoon JC, Breschi L, Pashley DH, Tay FR. (2010) Mineralisation of reconstituted collagen using polyvinylphosphonic acid/polyacrylic acid templating matrix protein analogues in the presence of calcium, phosphate and hydroxyl ions. Biomaterials 31:6618-6627

9. Kim J, Arola DD, Gu L, Kim YK, Mai S, Liu Y, Pashley DH, Tay FR. (2010) Functional biomimetic analogs help remineralize apatite-depleted demineralized resin-infiltrated dentin via a bottom-up approach. Acta Biomater 6:2740-2750

10. Toledano M, Sauro S, Cabello I, Watson T, Osorio R (2013) A Zn-doped etch-and-rinse adhesive may improve the mechanical properties and the integrity at the bonded-dentin interface. Dent Mater 29:e142-e152

11. Niu LN, Zhang W, Pashley DH, Breschi L, Mao J, Chen JH, Tay FR. (2014) Biomimetic remineralization of dentin. Dent Mater 30:77-96

12. Karlinsey RL, Hara AT, Yi K, Duhn CW (2006) Bioactivity of novel self-assembled crystalline Nb2O5 microstructures in simulated and human salivas. Biomed Mater 1:16-23

13. Obata A, Takahashi Y, Miyajima T, Ueda K, Narushima T, Kasuga T (2012) Effects of niobium ions released from calcium phosphate invert glasses containing Nb2O5 on osteoblast-like cell functions. ACS Appl Mater Interfaces 4:5684-5690 
14. Miyazaki T, Kim H, Kokubo T, Ohtsuki C, Nakamura T (2001) Apatite-forming ability of niobium oxide gels in a simulated body fluid. J Ceramic Soc Jpn 109:929-933

15. Leitune VC, Takimi A, Collares FM, Santos PD, Provenzi C, Bergmann CP, Samuel SM. (2013) Niobium pentoxide as a new filler for methacrylate-based root canal sealers. Int Endod J 46:205-210

16. Leitune VC, Collares FM, Takimi A, de Lima GB, Petzhold CL, Bergmann CP, Samuel SM. (2013) Niobium pentoxide as a novel filler for dental adhesive resin. J Dent 41:106-113

17. Provenzi C, Leitune VCB, Collares FM, Trommer RM, Bergmann CP, Samuel SM (2014) Interface evaluation of experimental dental adhesives with nanostructured hydroxyapatite incorporation. Appl Adh Sci 2:2. doi:10.1186/2196-4351-2-2

18. Kokubo T, Takadama H (2006) How useful is SBF in predicting in vivo bone bioactivity? Biomaterials 27:2907-2915

19. Szubert M, Adamska K, Szybowicz M, Jesionowski T, Buchwald T, Voelkel A (2014) The increase of apatite layer formation by the poly (3-hydroxybutyrate) surface modification of hydroxyapatite and beta-tricalcium phosphate. Mater Sci Eng C Mater Biol Appl 34:236-244

20. Collares FM, Portella FF, Leitune VC, Samuel S (2014) Discrepancies in degree of conversion measurements by FTIR. Braz Oral Res 28:9-15

21. PAS 132 (2007) Terminology for the Bio-Nano Interfaces. British Standards Institution, London, United King

22. Bohner M, Lemaitre J (2009) Can bioactivity be tested in vitro with SBF solution? Biomaterials 30:2175-2179

23. Pan H, Zhao X, Darvell BW, Lu WW (2010) Apatite-formation ability-predictor of "bioactivity"? Acta Biomater 6:4181-4188

24. Niu LN, Jiao K, Wang TD, Zhang W, Camilleri J, Bergeron BE, Feng HL, Mao J, Chen JH, Pashley DH, Tay FR. (2014) A review of the bioactivity of hydraulic calcium silicate cements. J Dent 42(5):517-533

25. Zadpoor AA (2014) Relationship between in vitro apatite-forming ability measured using simulated body fluid and in vivo bioactivity of biomaterials. Mater Sci Eng C Mater Biol Appl 35:134-143

26. International Organization for Standardization (2012) ISO 23317 Implants for surgery - In vitro evaluation for apatite-forming ability of implant materials. International Organization for Standardization, Geneva, Switzerland

27. Van Meerbeek B, Yoshihara K, Yoshida Y, Mine A, De Munck J, Van Landuyt KL (2011) State of the art of self-etch adhesives. Dent Mater 27:17-28

28. Profeta AC, Mannocci F, Foxton R, Watson TF, Feitosa VP, De Carlo B, Mongiorgi R, Valdré G, Sauro S. (2013) Experimental etch-and-rinse adhesives doped with bioactive calcium silicate-based micro-fillers to generate therapeutic resin-dentin interfaces. Dent Mater 29:729-741

29. Melo MA, Cheng L, Zhang K, Weir MD, Rodrigues LK, Xu HH (2013) Novel dental adhesives containing nanoparticles of silver and amorphous calcium phosphate. Dent Mater 29:199-210

30. Kokubo T, Kim HM, Kawashita M (2003) Novel bioactive materials with different mechanical properties. Biomaterials 24:2161-2175

doi:10.1186/s40563-014-0022-0

Cite this article as: Collares et al: Mineral deposition at dental adhesive resin containing niobium pentoxide. Applied Adhesion Science 2014 2:22.

\section{Submit your manuscript to a SpringerOpen ${ }^{\circ}$ journal and benefit from:}

- Convenient online submission

- Rigorous peer review

- Immediate publication on acceptance

- Open access: articles freely available online

- High visibility within the field

- Retaining the copyright to your article

Submit your next manuscript at $\boldsymbol{\nabla}$ springeropen.com 